\title{
The oldest evidence of non-coaxial shell heterostrophy in the Class Gastropoda
}

\author{
JIŘí FRÝDA \& LENKA FERROVÁ
}

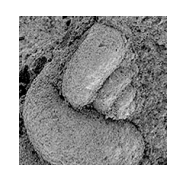

\begin{abstract}
The term shell heterostrophy describes the condition where the shell whorls coil in one direction during one portion of a gastropod's life, and in the other direction for another portion. In the present paper, the oldest evidence of non-coaxial shell heterostrophy in the Class Gastropoda is documented in the new species Koneprusellia zaki sp. nov. (Porcellioidea, Archaeogastropoda), coming from the Early Devonian of the Barrandian area (Bohemia). A brief analysis of the occurrences of this shell's morphological features, among the Paleozoic gastropods, revealed that the shell heterostrophy was present in at least three unrelated gastropod lineages: in the clades Heterobranchia (Devonian-Recent), Macluritoidea (Ordovician), and Porcellioidea (Silurian-Cretaceous). • Key words: Gastropoda, Paleozoic, Devonian, shell heterostrophy, Archaeogastropoda.
\end{abstract}

FRÝDA, J. \& FERROVÁ, L. 2011. The oldest evidence of non-coaxial shell heterostrophy in the Class Gastropoda. Bulletin of Geosciences 86(4), 765-776 (6 figures). Czech Geological Survey, Prague. ISSN 1214-1119. Manuscript received July 10, 2011; accepted in revised form September 6, 2011; published online October 14, 2011; issued November 16, 2011.

Jiři Frýda, Czech Geological Survey, P.O.B. 85, 11821 Prague 1, and Faculty of Environmental Sciences, Czech University of Life Sciences Prague, Kamýcká 129, Praha 6 - Suchdol, 165 21, Czech Republic; bellerophon@seznam.cz• Lenka Ferrová, Czech Geological Survey, P.O.B. 85, 11821 Prague 1; Lenka.Ferrova@ seznam.cz.

Bilateral symmetry is considered a primary state of the external body, as well as the internal organs, in the Bilateria. However, during their long evolution, external body asymmetry has evolved independently in some bilaterian groups. Additionally, many bilaterian groups, having an externally symmetrical body, exhibit bilateral asymmetry in shape and spatial arrangement of their internal organs. The origin and evolution of the asymmetry in the Bilateria is one of the frequently discussed topics of molecular and developmental biology (e.g., Asami et al. 2008, Kuroda et al. 2009, Hendricks 2009, Schilthuizen \& Haase 2010). In the case of body asymmetry, two enantiomorphic body plans are possible, which are symmetrical with respect to the plane (e.g. an arrangement and its mirror image). The reason why these enantiomorphs do not generally occur with the same frequency has hitherto been an unsolved question of evolutionary biology. In this context, gastropods probably represent the best known and most frequently studied asymmetric invertebrate animals.

The vast majority of gastropod shells are asymmetrically (anisostrophically) coiled, with most of them right-handed (dextral). Left-handed (sinistral) shells seem to be less common in the living, as well as in fossil gastropod groups (Wenz 1938, Knight et al. 1960, Pchelintsev \& Korobkov 1960, Vermeij 1975, Peel \& Horný 1996). Symmetrical gastropod shells are relatively rare, and have only been developed in a few gastropod groups. Regardless of the manner of shell coiling, the gastropod viscera are torted relative to the head-foot. This torsion of the soft body is one of the most typical (apomorphic); and thus, also a diagnostic characteristic for the class Gastropoda. The soft-body torsion is independent of shell coiling (Crofts 1955, Fretter \& Graham 1962). Thus, shell-less gastropods, or those with bilaterally symmetrical shells (e.g., Patellogastropoda), have torted viscera. Dextrality and sinistrality of the body torsion is determined very early in embryonic development, and once determined is never reversed (Robertson 1993).

Ueshima \& Asami (2003) showed that a single gene causes the mirror-image form of a gastropod body plan. Asami et al. (2008) demonstrated, with crossing experiments, that the primary asymmetry of freshwater pulmonate Lymnaea stagnalis (Linnaeus, 1758) is determined by the maternal genotype at a single nuclear locus, where the dextral allele is dominant over the sinistral allele. Therefore, it is not the genotype of individual animals that determines the handedness of the shell; but rather, it is the genotype of the mother that determines the phenotype of her progeny. Recently Kuroda et al. (2009) demonstrated that the chirality of gastropod shells could be changed by mechanical micromanipulation at an early embryonic stage. These authors noted that in Lymnaea stagnalis, the chiral 


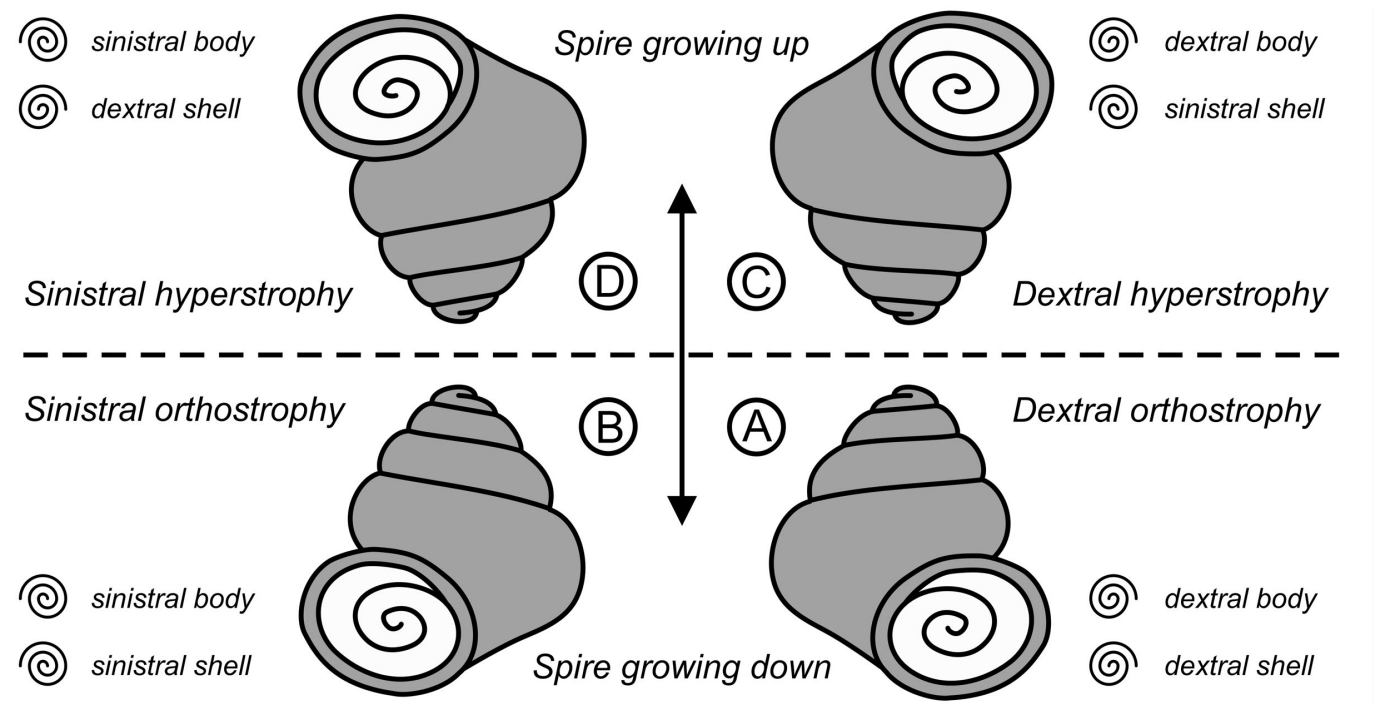

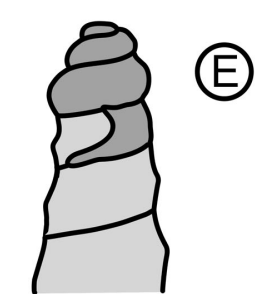

Homeostrophic

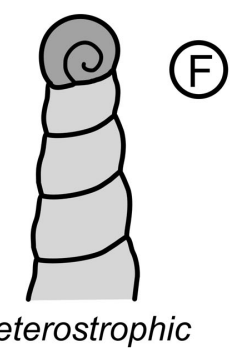

Figure 1. Schematic diagrams showing the four possible relationships between shell coiling and soft body asymmetry in the shell-bearing gastropods (A-D), as well as the relationship between the coiling of larval (protoconch II) and post-larval (teleoconch) shells (E, F). Orthostrophy (A and B) means that anatomically dextral (or sinistral) animals occupy dextrally (or sinistrally) coiled shells. On the other hand, the term hyperstrophy (C and D) is used for those cases that the handedness of the shell and soft body is different. Coiling of both parts of the shell in the same direction is termed homeostrophic (E). If handedness of these two parts is opposite, the coiling is termed heterostrophic (F).

blastomere arrangement at the eight-cell stage determines the left-right asymmetry throughout the developmental progress. Mechanical micromanipulation of the third cleavage chirality (from the four- to the eight-cell stage) leads to the reversal of embryonic handedness. These manipulated embryos grew to 'dextralized' sinistral, and 'sinistralized' dextral snails. The results of Kuroda et al. (2009) establish the crucial importance of the maternally-determined blastomere arrangement at the eight-cell stage in dictating the zygotic signaling pathways in the organismal chiromorphogenesis.

There are several hypotheses as to why gastropod species with shells coiled sinistrally are less common than species with dextrally coiled shells, which form more than 90\% of living gastropod taxa (Schilthuizen \& Davison 2005). Some of these hypotheses suggest that selection acts against the establishment of new coiling morphs, because two gastropods with dextral and sinistral shells would have trouble mating. Another hypothesis suggests that developmental constraint prevents the establishment of sinistral forms. Davison et al. (2009) studied the effect of coil phenotypes and genotypes on the fecundity and viability of fully self-fertilized hermaphrodite species (Lymnaea stagnalis), in addition to hermaphrodite species, which are rarely self-fertilized (Partula suturalis). These authors concluded that the sinistral genotype is associated with reduced egg viability in Lymnaea stagnalis; however, that individuals of the sinistral and dextral genotypes appear equally fecund in Partula suturalis. Later, Schilthuizen \& Haase (2010) studied chiral dimorphisms in Amphidromus Albers, 1850, a land snail genus that is consistently chirally dimorphic. They found that selection based upon the shape differences of the sinistral and dextral forms is either very weak or constrained by the fact that the pleiotropic effects of the chirality gene are only of importance very early in development. Surprisingly, they demonstrated a subtle, but detectable, shell shape difference between the dextral and sinistral individuals, which derived from the same gene pool.

Rules controlling the occurrences of gastropods with sinistrally coiled shells in the marine ecosystem are less well studied than those for land and freshwater gastropods. Hendricks (2009) noted that most specimens of the aberrantly sinistral modern Conus Linnaeus, 1758, are derived from typically dextral species that have a nonplanktonic development. He also suggested that this may have been a critical factor for the early establishment of sinistral species in the marine gastropods. Taken together, recent molecular and ecological studies of living gastropods show that the origin of gastropod lineages with sinistrally coiled shells, and their evolutionary success is probably controlled by several different mechanisms, which still are not completely understood.

Because of the independence of the soft-body torsion and shell coiling, there are four possible combinations of soft-body organization and shell coiling in the gastropods: anatomically dextral, as well as sinistral animals; either which may have dextrally or sinistrally coiled shells. These four types of geometrical arrangements in shellbearing gastropods (Fig. 1) were recognized more than 100 years ago (Pelseneer 1893). The different arrangements of soft body and shell coiling may be described 

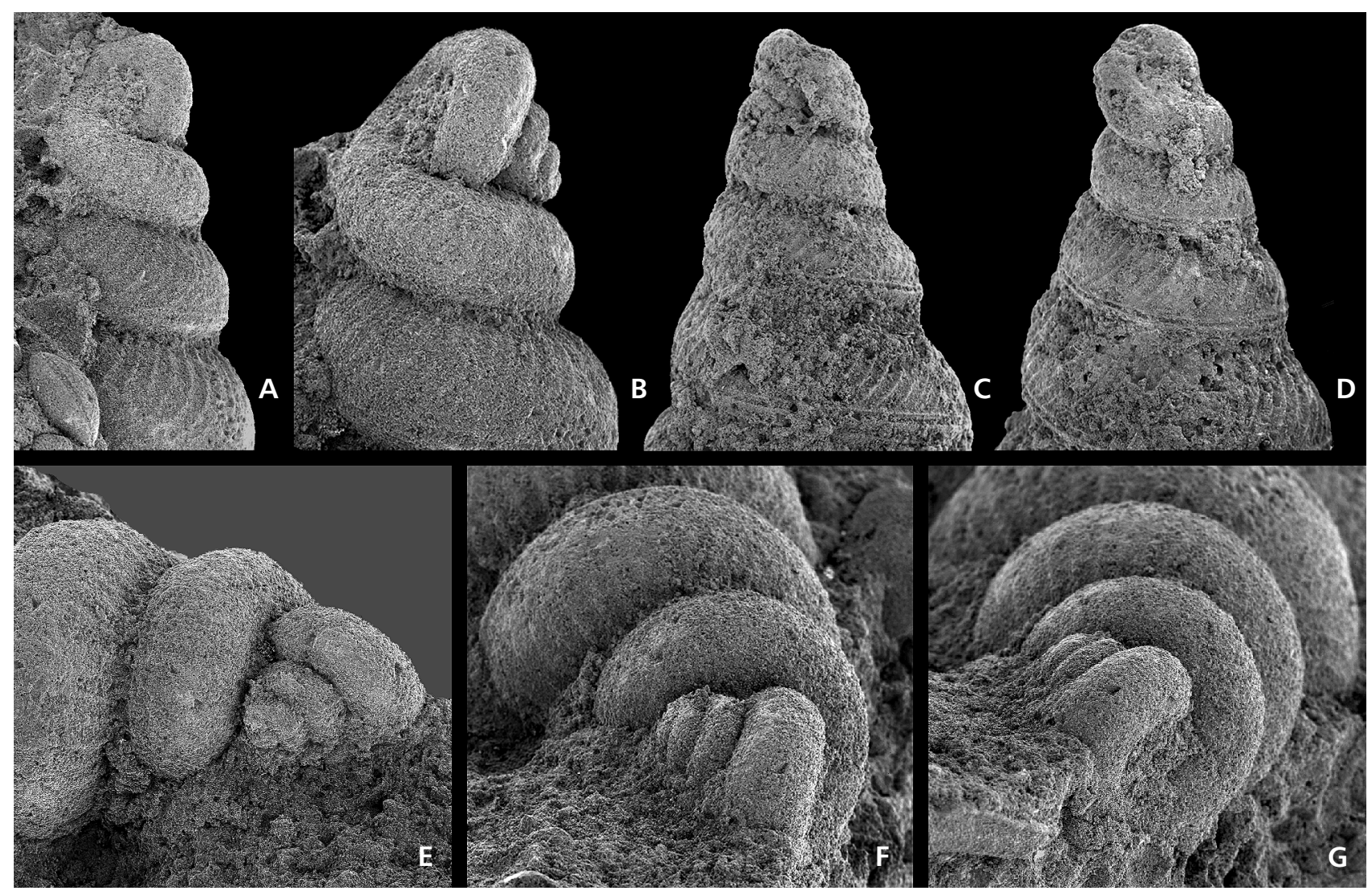

Figure 2. Juvenile part of teleoconchs in the agnesiid gastropod Koneprusellia zaki sp. nov. from the Koněprusy Limestone (Pragian, Early Devonian), showing distinct non-coaxial shell heterostrophy. $\bullet$ A, B - lateral views of holotype (UUG JF 895). $\bullet$ C, D - lateral views of paratype A (UUG JF 896 ). - E-G - lateral, oblique apical, and apical views of the holotype. A × 20; B × 26; C, D × 16; E × 27; F, G × 29 .

in the terms discussed in detail by Knight (1952). Anatomically dextral animals with dextrally coiled shells are termed dextral orthostrophic (Fig. 1A). The mirror image of that (i.e., an anatomically sinistral animal with a sinistrally coiled shell) is the sinistral orthostrophic (Fig. 1B). However, an anatomically dextral animal with a sinistrally coiled shell is called dextral hyperstrophic, with the mirror image of that being the sinistral hyperstrophic (Fig. 1C, D).

This pattern may even be more complex. There are several gastropod groups, in which the shell whorls coil in one direction during one portion of their life, and in the other direction for another portion. The term heterostrophy (Fig. 1F) has been used for this condition (e.g., Knight 1941, 1952). If the shell axes of the sinistrally and dextrally coiled shells are parallel, then the term coaxial shell heterostrophy should be used for this arrangement. Shells with both axes not being parallel may be termed either as non-coaxial heterostrophic or inclined heterostrophic (Frýda \& Blodgett 1998).

In this short paper, we report the oldest non-coaxial shell heterostrophy in the class Gastropoda, which is documented here in the Pragian (Early Devonian) species
Koneprusellia zaki sp. nov., belonging to the superfamily Porcellioidea Koken in Zittel, 1895. This finding may shed light not only on the evolution of the shell heterostropy in the porcellioidean gastropods, but also may help us to understand why some gastropods change the direction of their shell coiling during different ontogenetic stages.

\section{Systematic paleontology}

Class Gastropoda Cuvier, 1797

Subclass Archaeogastropoda Thiele, 1925

Order Vetigastropoda Salvini-Plawen, 1980

Superfamily Porcellioidea Koken in Zittel, 1895

Families included. - Porcelliidae Koken in Zittel, 1895 and Cirridae Cossmann, 1916.

Family Porcelliidae Koken in Zittel, 1895

Subfamily included. - Porcelliinae Koken in Zittel, 1895, and Agnesiinae Knight, 1956. 


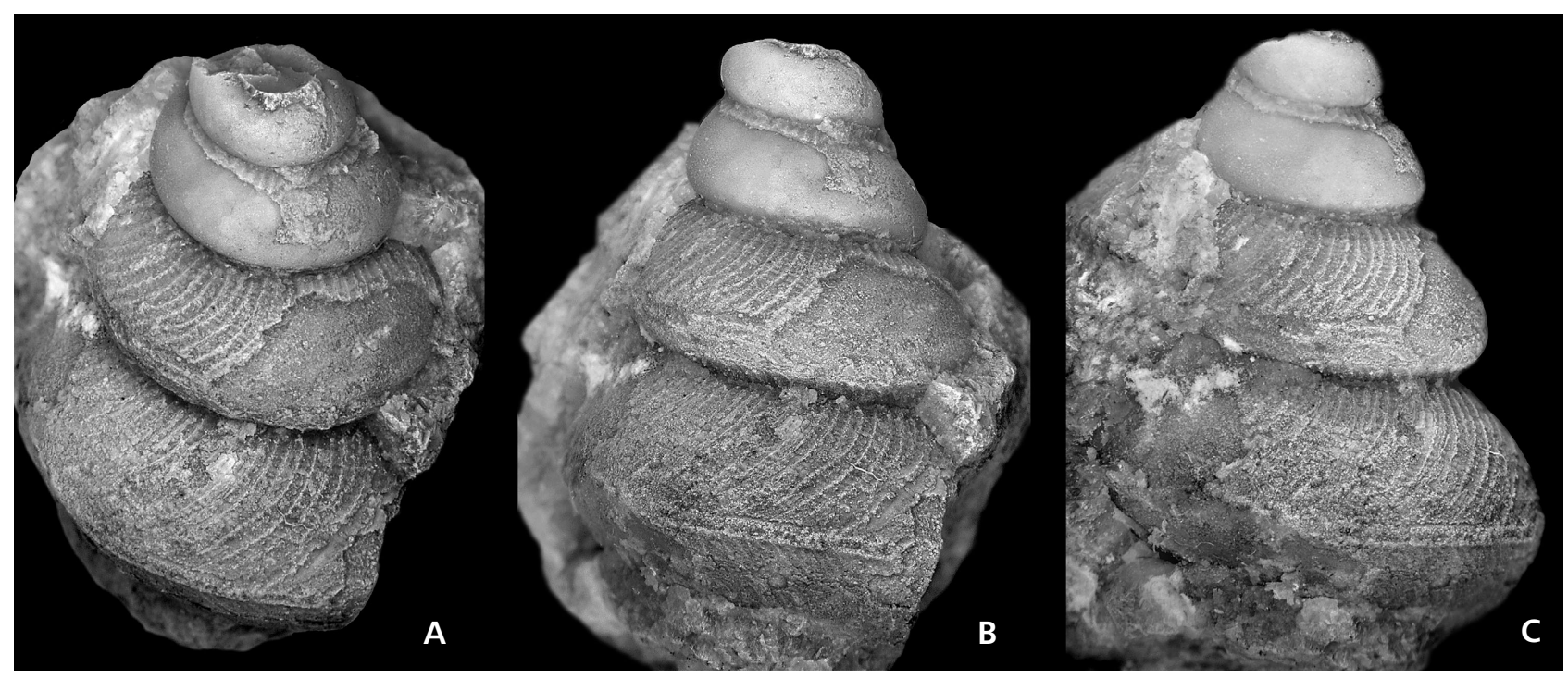

Figure 3. Holotype of Agnesia invertens Barrande in Perner (1907, pp. 87, 88) and the type species of the genus Koneprusellia (the National Museum, Prague, type number L 11404) from the Pragian (Lower Devonian) Koněprusy Limestone. • A-C - oblique lateral and two lateral views of the holotype; note spiral threads crossing the collabral costae on the shell surface between the upper whorl suture and selenizone. All views $\times 9$.

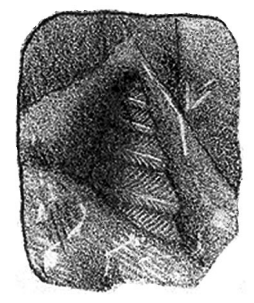

A

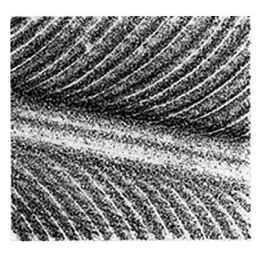

B

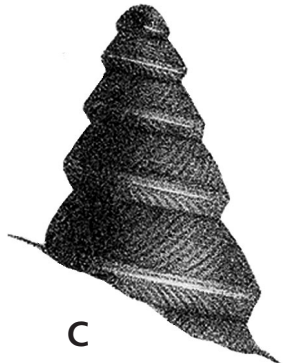

conch whorls; teleoconch with or without apertural slit (diagnosis emended by Frýda et al. 2008).

Remarks. - The generic content of the subfamily Agnesiinae was summarized by Frýda \& Farrell (2005). The oldest member of the Agnesiinae, Pernericirrus sinistorsus (Perner, 1907), was reported from Late Silurian strata of the Barrandian area (Frýda 1997). It occurs within the Prionopeltis archiaci-Atrypoidea modesta Community (Havlíček \& Štorch 1990), which was the first highly diversified faunal community after the recovery following the midLudfordian positive carbon isotope excursion and LAU bioevent (Manda \& Kř́iž 2006, Lehnert et al. 2007, Slavík et al. 2010) and before Silurian-Devonian boundary bioevent (Manda \& Frýda 2010). The Agnesiinae reached their highest diversity and morphological disparity during the Early and Middle Devonian; thus, during the time of major changes of the marine communities, and increasing predation pressure on the benthic as well as the planktic organisms (see Signor \& Brett 1984, Brett 2003, Berkyová et al. 2007, Klug et al. 2010), which also influenced the ontogenetic strategies of gastropods (Nützel \& Frýda 2003, but see also Nützel et al. 2006, 2007). The Triassic Enantiostoma Koken, 1896, probably represents the youngest and only post-Paleozoic member of the Agnesiinae. However, its early teleoconch morphology is still unknown; therefore, no unequivocal evidence exists that any members of the Agnesiinae or Porcelliinae survived the Permian/Triassic extinction event.

Genera included. - Agnesia de Koninck, 1883, Alaski-

ella Frýda \& Blodgett, 1998, Anoriostoma Farrell, 1992,
Diagnosis. - Porcelliids with a sinistrally coiled, trochiform teleoconch and with dextrally coiled initial teleo- 


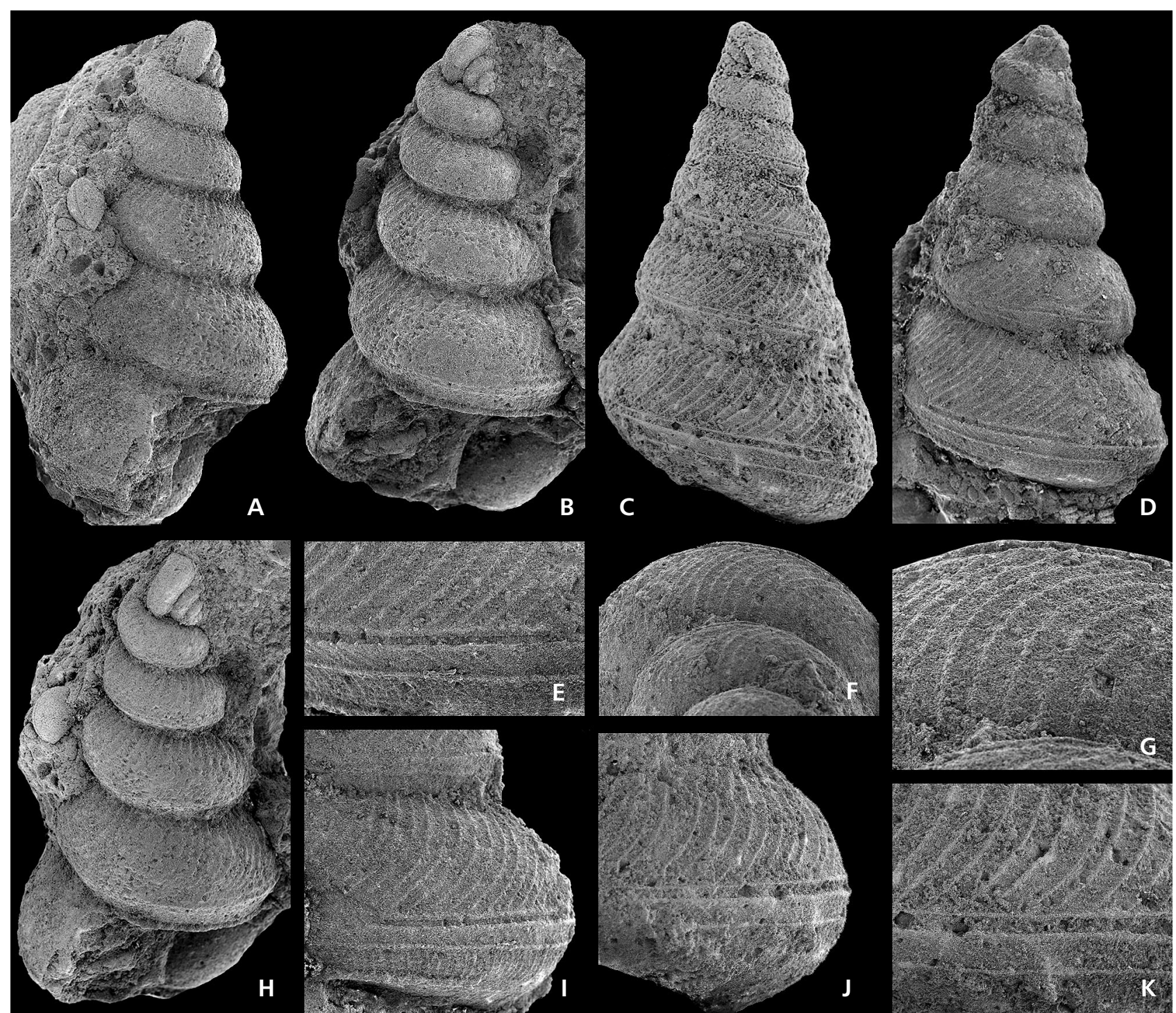

Figure 5. The Pragian (Early Devonian) agnesiid gastropod Koneprusellia zaki sp. nov., from the Koněprusy Limestone (Barrandian area). • A, B - lateral views of holotype (UUG JF 895). • C - lateral view of paratype A (UUG JF 896). $\bullet$ D - lateral view of paratype B (UUG JF 897). $\bullet$ E, I - detailed views of final whorl in the paratype B, showing distinct spiral cord and fine threads below the selenizone and shape of the whorl profile. $\bullet F, G-$ oblique apical views of adult teleoconch whorls, showing a shell ornamentation above the selenizone. $\bullet \mathrm{H}-$ oblique view of holotype (UUG JF 895). $\bullet$ J, $\mathrm{K}$ - detailed views of final whorl in paratype A, showing shell ornamentation and shape of the whorl profile. A, B × 12; C, D × 11; $\mathrm{E} \times 20 ; \mathrm{F}, \mathrm{H} \times 12 ; \mathrm{G} \times 32 ; \mathrm{I} \times 15 ; \mathrm{J} \times 17 ; \mathrm{K} \times 39$.

Antitrochus Whidborne, 1891, Garraspira Frýda \& Farrell, 2005, Hesperiella Holzapfel, 1889, Koneprusellia Frýda, 1998, Krolmusium Horný, 2002, Paragnesia Blodgett \& Frýda, 1999, Pauquysia Frýda, 2004, Pernericirrus Frýda, 1997, Perryconcha Frýda, Blodgett, Lenz \& Manda, 2008, Sasakiela Bandel \& Frýda, 2004, Trochagnesia Heidelberger, 2001, and Enantiostoma Koken, 1896.

\section{Genus Koneprusellia Frýda, 1998}

Type species. - Species described as Agnesia invertens Barrande by Perner (1907, pp. 87, 88). Its holotype (the
National Museum, Prague, L 11404; Fig. 3) comes from the Lower Devonian Koněprusy Limestone (Praha Formation) of Pragian age (for a detailed discussion of stratigraphy see Slavík 2004 and Carls et al. 2008; for a list of papers dealing with geology of the Praha Formation see Manda \& Turek 2009), exposed south of the village of Koněprusy, in the Barrandian area.

Emended diagnosis. - Sinistrally coiled shell, with a spire angle ranging from 35 to 45 degrees; wide deep V-shaped sinus, culminating in a narrow slit generating a selenizone; upper and lower margins of the labral sinus containing nearly a right angle close to the slit; narrow selenizone at the 


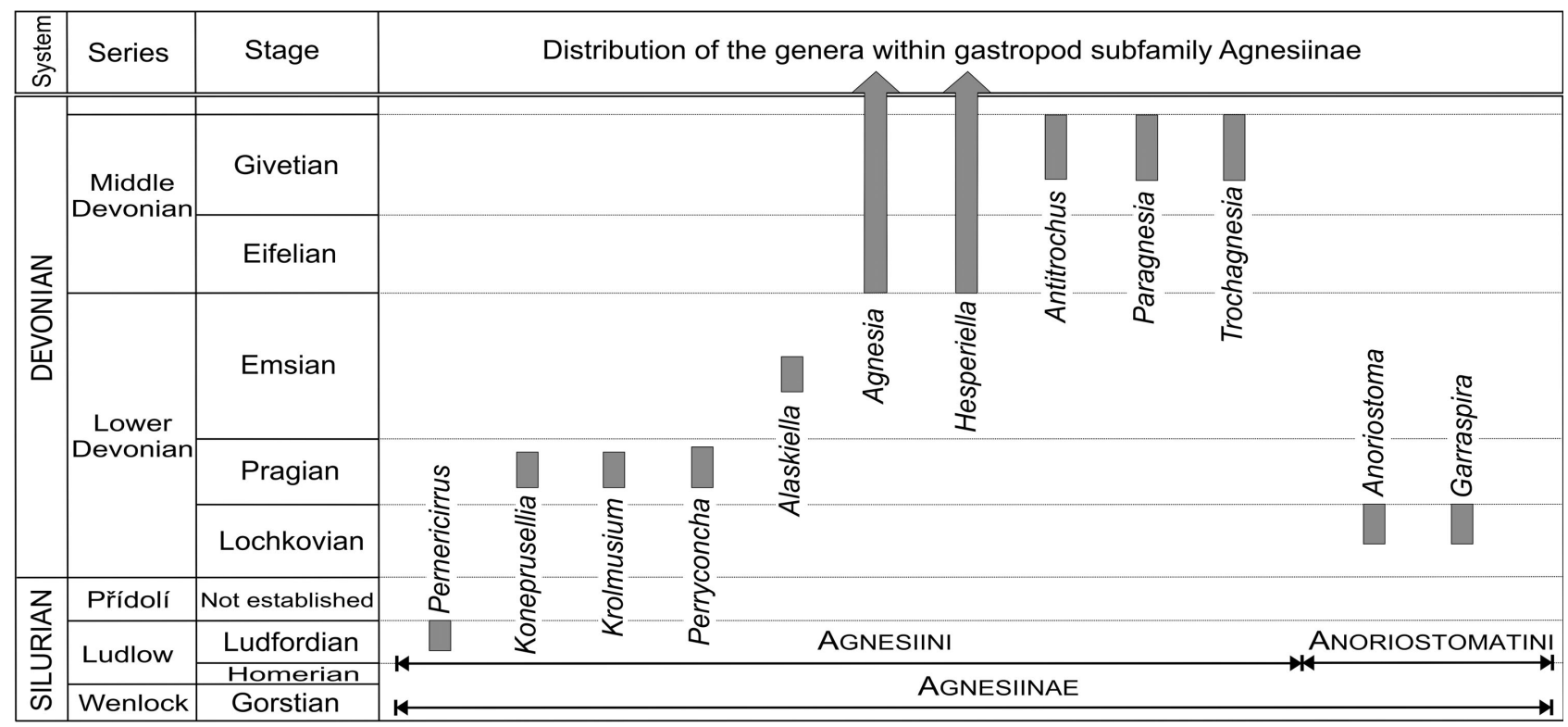

Figure 6. Stratigraphic distribution of Silurian and Devonian genera and subgenera of the gastropod subfamily Agnesiinae Knight, 1956.

whorl periphery is situated closer to the lower, than the upper, suture; shell ornamentation consisting of regularly spaced collabral costae (Figs 2,3 and 5); distinct spiral cord developed below the selenizone, at a distance about double the selenizone width (Fig. 5); initial part of shell dextrally coiled (Fig. 2); axis of dextrally coiled initial shell enclose obtuse angle with the axis of the teleoconch (non-coaxial heterostrophy).

Remarks. - Several specimens of sinistral coiled shells, which closely resemble the shell described and figured by Perner (1907, pl. 98, figs 12-14) as Agnesia invertens Barr., were collected by the senior author of the present paper from the Koněprusy Limestone in the period 1990-1995 [unfortunately the holotype of the latter species, deposited in the National Museum, Prague (L 11404; Fig. 3), was not accessible at that time]. These shells differ from all known Agnesia species, as well as from all other species of the subfamily Agnesiinae Knight, 1956. For this reason, a new genus Koneprusellia was established for Agnesia invertens Barrande in Perner, 1907, which was selected as its type species (Frýda 1998). Placement of the genus Koneprusellia to the Agnesiinae was based on the general teleoconch features, even thought the most typical diagnostic character of the Agnesiinae (i.e., dextrally coiled early teleoconch whorls) was not documented in its type (and only known) species. Much betterpreserved and richer material was collected in 2006 by the junior author of the present paper from weathered Koněprusy Limestone at the fourth floor (No. 345) of the Císařský lom Quarry. This new material revealed several new shell features (Figs 2, 5), which suggest a placement of
Koneprusellia within the Agnesiinae, and make emendation of its generic diagnosis possible.

However, study of the currently accessible holotype of Agnesia invertens Barrande in Perner, 1907 (National Museum, Prague, L 11404; Fig. 3), showed, that this specimen is not identical with newly-collected specimens, and probably also not with the specimen figured by Perner in plate 98 (figs 12-14; Fig. 4 herein). No additional specimen was figured by Perner (1903-1911) or deposited in his documented fossil materials. Perner (1907, pp. 87, 88) described the species Agnesia invertens Barrande in Perner, 1907, using the specimen deposited today in the National Museum, Prague (i.e., specimen L 11404). Therefore, this shell must be considered to be the holotype of Agnesia invertens Barrande in Perner, 1907. Differences of the figured specimen (Fig. 4) and the specimen used for the description of Agnesia invertens (Fig. 3) had already been recognized by Perner (1907, pp. 87, 88). The spire angle of the holotype (National Museum, Prague, L 11404) is about 45 degrees, but only about 38 degrees in the figured shell (Fig. 4). The latter specimen was probably even lost before Perner's study (he used older plates, which had been made during Barrande's life in Paris), which makes its detailed comparison with the holotype of Agnesia invertens impossible.

Newly collected shells are smaller than the holotype of Agnesia invertens, and their largest whorls have roughly the same width as the first preserved whorl in the holotype (Fig. 3). Unfortunately, the holotype is lacking the initial part of the teleoconch. The presence of a distinct spiral cord located below the selenizone (traces of which were found in the holotype; Fig. 3), as well as of similar shape of the 
sinistrally coiled teleoconchs, with a narrow selenizone at the whorl periphery and a distinct collabral plus regularly spaced costae, suggest that Agnesia invertens and the newly gathered species (Figs 2, 5) may be placed in the same genus. Taken together, the newly gathered fossil materials in 1990-1995 and in 2006 may belong to another species of the Koneprusellia (probably related to a species which was available to Barrande; see note with Fig. 4), than to the the specimen described by Perner (1907) as Agnesia invertens Barrande in Perner, 1907 (specimen L 11404).

Comparison. - Species of the Koneprusellia having highspired and sinistrally coiled shells differ from all species belonging to the agnesiid genera Agnesia, Anoriostoma, Antitrochus, Garraspira, Krolmusium, Paragnesia, Pernericirrus, Perryconcha, Sasakiela, Trochagnesia, and Enantiostoma. All of the genera may also be distinguished from the Koneprusellia species by many another shell features [see their detailed descriptions or re-descriptions in Knight (1941), Farrell (1992), Frýda (1997, 2004), Frýda \& Blodgett (1998, 1999), Heidelberger (2001), Horný (2002), Frýda \& Farrell (2005), and Bandel \& Frýda (2004)]. The high-spired teleoconchs occur in species of Alaskiella, Hesperiella, and Pauquysia. Species of the last two genera differ from Koneprusellia by having a flat top of their teleoconchs, with a central depression formed by the umbilicus of dextrally coiled early teleoconch whorls. Additionally, the only known species of Pauquysia has an openly coiled first whorl (Frýda 2004, fig. 2). The Emsian (Early Devonian) species Alaskiella medfraensis Frýda \& Blodgett, 1998, also being the only hitherto known species of the Alaskiella, has (as the only agnesiid) a similar shape of the early teleoconch with species of the Koneprusellia (see figures in Frýda \& Blodgett 1998, 2004). Both of the latter genera differ by their early teleoconch shape, by the whorl shape near to their selenizone, and by their shell ornamentation. The axis of the dextrally coiled early teleoconch whorls shows an angle of 155 degrees, with an axis of adult teleoconch spire in Alaskiella, but only of about 120 degrees in Koneprusellia. In addition, the dextrally coiled initial portion of the teleoconch consists of two whorls in the first genus, but three shell whorls in the latter genus. In addition, the shape of the whorl profile near the selenizone is quite different in both genera. In Alaskiella medfraensis, the whorl profile between the upper suture and the selenizone is very gently convex and has an angle of about 45 degrees with the teleoconch axis. The whorl profile is distinctly concave just above the protruding flanges bordering the selenizone. The concave selenizone is situated at the whorl periphery and is bordered by two protruding flanges, one on each side in Alaskiella (see figures in Frýda \& Blodgett 1998). On the other hand, the whorl profile between the upper suture and the selenizone is distinctly convex in both species of Koneprusellia, and the narrow selenizone is situated at the whorl periphery, without protruding flanges (Fig. 5). Moreover, both species of Koneprusellia have a distinct spiral cord below the selenizone (Fig. 5). The regularly spaced costae are another shell characteristic distinguishing both of the species of Koneprusellia, K. invertens (Barrande in Perner, 1907) and K. zaki sp. nov. from Alaskiella medfraensis.

Species included. - Koneprusellia invertens (Barrande in Perner, 1907) and Koneprusellia zaki sp. nov.; both coming from the Lower Devonian strata (Pragian; Koněprusy Limestone, Praha Formation) of the Barrandian area.

Koneprusellia zaki sp. nov. Figures 2A-G, 5A-K

Etymology. - Named after the late professor of mineralogy at Charles University, Prague, Lubor Žák (1925-2008), enthusiastic scientist, honest, and God-fearing man.

Diagnosis. - Species of Koneprusellia with a spire angle of about 35 degrees, and lacking spiral threads crossing the collabral costae on the shell surface above the selenizone (Fig. 5); axis of the dextrally coiled early teleoconch and axis of the adult teleoconch enclose an angle of 120 degrees; the dextrally-coiled part of the teleoconch consists of three whorls; the sinistrally-coiled part of the teleoconch comprises five whorls; a narrow selenizone situated at whorl periphery; collabral and regularly spaced costae on shell surface above the selenizone enclose an angle of about 45 degrees with the selenizone; collabral costae below the selenizone crossed by distinct spiral cord (Fig. 5C-E, I-K); collabral costae below the spiral cord curving back and crossed by fine spiral threads (Fig. 5E, I).

Type locality. - Císařský lom Quarry, S of village of Koněprusy, Czech Republic.

Type horizon. - Middle part of the Koněprusy Limestone, Praha Formation.

Holotype. - Specimen figured, herein, as Fig. 2A, B, E-G; UUG JF 895, Czech Geological Survey, Prague.

Paratypes. - Paratype A, herein figured as Figs 2C, D, and 5C, J, K (UUG JF 896), and paratype B as Fig. 5D, E, I (UUG JF 897). Additional paratypes are 9 unfigured specimens (UUG JF 898-906), Czech Geological Survey, Prague.

Description. - Moderately sized, sinistrally-coiled, high-spired shell with dextrally coiled initial whorls 
(Fig. 1); the youngest three teleoconch whorls form a trochiform, distinctly dextrally-coiled shell with a spire angle of about 65 degrees; apex of the sinistral teleoconch obtuse, and formed by lateral side of dextrally coiled whorl of early teleoconch; axis of the dextrally coiled early teleoconch and axis of the adult teleoconch enclose an angle of 120 degrees; sinistrally coiled teleoconch comprises five whorls; base of the shell anomphalous or minutely phaneromphalous; spire angle of about 35 degrees; sutural slope about 10 degrees; sutures relatively deep; whorl profile between sutures distinctly convex; narrow selenizone situated at the whorl periphery; selenizone developed at least from the first sinistrally-coiled whorl of the teleconch (its presence on dextrally coiled whorls is uncertain because of their preservation); selenizone close to the lower suture, its distance from the lower suture about one fourth part of its distance from the upper suture (Fig. 2); distance between sutures about ten times wider than width of concave selenizone; collabral and regularly spaced costae on shell surface above the selenizone having an angle about 45 degrees with the selenizone; distinct spiral cord developed below the selenizone on sinistrally coiled teleoconch whorls, collabral costae between selenizone and spiral cord having an angle of about 40 degrees with the selenizone; distance between adjacent collabral costae larger than the selenizone width; below the spiral cord, collabral costae curving back and being crossed by fine spiral threads (Fig. 5E, I).

Comparison. - Both known species of Koneprusellia, K. invertens (Barrande in Perner, 1907), and K. zaki sp. nov., come from the Koněprusy Limestone of Pragian age (Early Devonian). The latter species differs from $K$. invertens by a much narrower spire and by the lack of spiral threads crossing the collabral costae on the shell surface above the selenizone (compare Fig. 3A with 5E-K).

\section{Shell heterostrophy in Paleozoic gastropods}

Shell heterostrophy is a typical characteristic of the clade Heterobranchia, which together with the caenogastropod clade forms the most successful group of living gastropods (Wägele et al. 2008). In Heterobranchia, the change of shell coiling direction (from sinistral to dextral or vice versa) occurs during metamorphosis at the protoconch/teleoconch boundary. This type of shell heterostrophy (i.e., larval heterostrophy) is considered to be apomorphic of the Heterobranchia; it occurs in all heterobranchs where planktotrophic larvae have been developed. The coaxial heterostrophic protoconch of the Mesozoic Tofanellidae Bandel, 1995, represents a special case: switch from sinistral to dextral coiling direction occurs within the larval stage i.e., before metamorphosis. The fossil record of the heterobranch gastropods is relatively rich in Tertiary and Meso- zoic strata (Wenz 1938; Pchelintsev \& Korobkov 1960; Bandel 1994, 1995, 1996; Kaim 2001, 2004). The Heterobranchia have also been well documented from late Paleozoic strata, the vast majority of them belonging to the superfamily Streptacidoidea Knight, 1931. The Givetian (late Middle Devonian) genus Heteroloxonema Frýda, 2000 represents the oldest known streptacidoidean genus. Three different heterobranchian groups were documented among Paleozoic gastropods (Frýda \& Blodgett 2001, 2004; Bandel \& Heidelberger 2002; Bandel 2002; Pan Hua-Zhang et al. 2003): the Streptacidoidea (Middle Devonian?, Early Carboniferous-Late Permian; Allogastropoda Haszprunar, 1985), Stuoraxidae Bandel, 1994 (Late Permian, Architectonicoidea Gray, 1850), and Kuskokwimiidae Frýda \& Blodgett, 2001 (Emsian, Early Devonian). The latter group represents the hitherto oldest evidence for the clade Heterobranchia.

The oldest evidence of shell heterostrophy in the class Gastropoda was documented by Frýda \& Rohr (2006) in Macluritella stantoni Kirk, 1927, from the Early Ordovician of Colorado. The early whorls of this species are openly and dextrally coiled; the later teleoconch whorls are sinistrally coiled (as in all members of the Macluritoidea Carpenter, 1861). This type of coaxial sinistral heterostrophy differs from the larval heterostrophy of the Heterobranchia, because the changes in the shell coiling took place during later post-larval ontogeny. The spiral operculum of the Ordovician genus Maclurites Le Sueur, 1818, is sinistrally (counterclockwise) coiled, and therefore all macluritids were interpreted as dextral hyperstrophic (Woodward 1854, Knight 1952). The fact that the macluritids have been interpreted as dextrally hyperstrophic, and that early whorls are dextrally coiled in the oldest macluritid genus (in Macluritella), have a significant implication for the interpretation of macluritid phylogeny. Macluritella may be interpreted as dextrally orthostrophic during its early ontogeny, and thus at this ontogenetic stage it had the same type of the soft bodyshell arrangement (anatomically dextral body in a dextrally coiled shell) as the vast majority of living and fossil gastropods. The latter interpretation of the oldest macluritid genus suggested that the Macluritoidea evolved from the dextrally orthostrophic gastropods, and dextral hyperstrophy is their derivative, and not a primary shell feature (Frýda \& Rohr 2006). The phylogenetic relationships of the Macluritoidea, as well as their subsequent fate, are still a matter of discussion (Linsley \& Kier 1984; Dzik 1983; Frýda 1992; Wagner 1999; Frýda \& Rohr 2004, 2006).

A similar type of shell heterostrophy (i.e. change in handedness of the shell coiling occurs during teleoconch growth) was documented in the Paleozoic Porcelliidae Koken in Zittel, 1895, which belong to (or is close to) the order Vetigastropoda (see discussion above). Within porcellioidean gastropods, both coaxial and non-coaxial 
heterostrophy were reported (Bandel 1993, Frýda \& Blodgett 1998). The Ludfordian (Late Silurian) Pernericirrus sinistorsus (Perner, 1907), developing the coaxial shell heterostrophy, is the oldest porcellioidean gastropod (Frýda 1997). Here, the porcellioidean gastropod described, Koneprusellia zaki sp. nov., represents the oldest evidence of non-coaxial shell heterostrophy in the class Gastropoda. It is noteworthy that the oldest evidence of non-coaxial shell heterostrophy was found in clade Archaeogastropoda. Only several examples of a deviation from regular shell coiling have been hitherto reported within fossil archaeogastropods (e.g., in Triassic member of genus Eucycloscala Cossmann, 1895; see Bandel 1993, 2010).

Some Paleozoic gastropods even changed the manner of their shell coiling during late shell ontogeny. However, in these cases, the opposite handedness of shell coiling only occurs in the final teleoconch whorl. Members of family Scoliostomatidae Frýda, Blodgett \& Lenz, 2002 provide the best example of such a gastropod group among the Paleozoic gastropods.

\section{Conclusion}

The term shell heterostrophy describes those conditions when shell whorls coil in one direction during a portion of gastropod life, and in the other direction for the another portion. This shell feature occurs in several unrelated groups of Paleozoic gastropods:

1. Larval heterostrophy (manner of shell coiling is changed during anatomical and physiological reorganization the larval body into juvenile, post-larval body) is limited only to the clade Heterobranchia. Both the coaxial and non-coaxial heterostrophy have been reported among $\mathrm{Pa}-$ leozoic, as well as post-Paleozoic heterobranchs.

2. The oldest evidence of shell heterostrophy in the Class Gastropoda was documented in macluritid Macluritella stantoni Kirk, 1927, from Early Ordovician strata of Colorado, which developed the coaxial shell heterostrophy.

3. The oldest evidence of non-coaxial shell heterostrophy in the Class Gastropoda is reported here in the Pragian (Early Devonian) porcellioidean gastropod Koneprusellia zaki sp. nov. from the Barrandian area.

\section{Acknowledgments}

This study was supported by the Czech-American Cooperation Programme (Kontakt ME08011) and the Grant Agency of the Czech Republic (P210/11/1891). We thank Michal Hejna (Tetín) for his kind help during our fieldwork at the Císařský lom Quarry and Martin Valent (Praha) for photos of specimen L 11404 (Fig 3). We also wish to acknowledge Alex Nützel (München) and Andrzej Kaim (Warszawa) for their helpful, critical reviews of this paper.

\section{References}

Aktipis, S.W. \& GiRibet, G. 2010. A phylogeny of Vetigastropoda and other "archaeogastropods": re-organizing old gastropod clades. Invertebrate Biology 129(3), 220-240.

DOI 10.1111/j.1744-7410.2010.00198

Albers, J.C. 1850. Die Heliceen, nach natürlicher Verwandtschaft systematisch geordnet. 262 pp. Verlag von Th. Chr. Fr. Enslin, Berlin.

Asami, T., Gittenberger, E. \& Falkner, G. 2008. Whole-body enantiomorphy and maternal inheritance of chiral reversal in the pond snail Lymnaea stagnalis. Journal of Heredity 99(5), 552-557. DOI 10.1093/jhered/esn032

BANDEL, K. 1993. Evolutionary history of sinstral archaeogastropods with and without slit (Cirroidea, Vetigastropoda). Freiberger Forschungshefte, Paläontologie C450, 41-82.

Bandel, K. 1994. Triassic Euthyneura from St. Cassian Formation (Italian Alps) with a discussion on the evolution of the Heterostropha. Freiberger Forschungsheft, Serie C 452, 79-100.

BANDEL, K. 1995. The Mathildoidea from the Upper St. Cassian Formation. Scripta Geologica 111, 1-83.

BANDEL, K. 1996. Some heterostrophic gastropods from Triassic St. Cassian Formation with a discussion of the classification of the Allogastropoda. Paläontologische Zeitschrift 70(3/4), $325-365$.

BANDEL, K. 2002. About the Heterostropha (Gastropoda) from the Carboniferous and Permian. Mitteilungen aus dem Geologisch-Paläontologischen Institut der Universität Hamburg $86,45-80$.

BANDEL, K. 2010. Relationships of the Triassic Eucycloidea Koken, 1897 (Mollusca, Gastropoda) to modern genera such as Pagodatrochus, Calliotropis and Euchelus, based on morphology of the early shell. Bulletin of Geosciences 85(3), 435-486. DOI 10.3140/bull.geosci.1208

BANDEL, K. \& FRÝDA, J. 2004. Sasakiela, a new Early Carboniferous porcelliid genus (Porcellioidea, Gastropoda) with an unusual shell ontogeny. Neues Jahrbuch, Geologisch-Paläontologische Monatshefte 3, 135-150.

Bandel, K. \& Heidelberger, D. 2002. A Devonian member of the subclass Heterostropha (Gastropoda) with valvatoid shell shape. Neues Jahrbuch für Geologie und Paläontologie, Monatshefte 9, 503-550.

Berkyová, S., FrÝdA, J. \& LuKeš, P. 2007. The first documentation of unsuccessful predation on the Middle Paleozoic plankton. Acta Palaeontologica Polonica 52(2), 407-412.

BlodgetT, R.B. \& FRÝdA, J. 1999. New Devonian gastropod genera important for paleogeographic reconstructions. Journal of the Czech Geological Society 44, 293-308.

Bouchet, P., Rocroi, J.P., Frýda, J., Hausdorf, B., Ponder, W., VAldes, A. \& WARÉN, A. 2005. Classification and nomenclator of gastropod families. Malacologia 47(1-2), 1-368.

BretT, C.E. 2003. Durophagous predation on Paleozoic marine benthic assemblages, 401-432. In Kelley, P.H., KowalewsKi, M. \& Hansen, T. (eds) Predator-Prey Interactions in the Fossil Record, Topics in Geobiology. Kluwer Academic/Plenum Publishers, New York.

Carls, P., Slavík, L. \& Valenzuela-Ríos, J.I. 2008. Comments on the GSSP for the basal Emsian stage boundary: the need for 
its redefinition. Bulletin of Geosciences 83(4), 383-390. DOI 10.3140/bull.geosci.2008.04.383

CARPEnTER, P.P. 1861. Lectures on Mollusca; or "shell-fish" and their allies. Annual Report of the Board of Regents of the Smithsonian Institution for 1860, 151-283.

Cossmann, M. 1915. Révision de scaphopodes, Gastéropodes, et Céphalopodes du Montien des la Belgique. Mémoires du Musée Royal d'Histoire Naturelle de Belgique 6, 1-71.

Cossmann, M. 1916. Essais de paléoconchologie comparée, volume 10. 292 pp. Chez l'auteur, Paris.

CROFTS, D.R. 1955. Muscle morphogenesis in primitive gastropods and its relation to torsion. Proceedings of the Zoological Society of London 125, 711-750.

CuVIER, G. 1797. Tableau élémentaire de l'histoire naturelle des animaux. 710 pp. Baudouin, Paris.

Davison, A., Barton, N.H. \& Clarke, B. 2009. The effect of coil phenotypes and genotypes on the fecundity and viability of Partula suturalis and Lymnaea stagnalis: implications for the evolution of sinistral snails. Journal of Evolutionary Biology $22,1624-1635$. DOI 10.1111/j.1420-9101.2009.01770.x

DzIK, J. 1983. Larval development and relationships of Mimospira - a presumably hyperstrophic Ordovician gastropod. Geologiska Föreningens i Stockholm Förhandlingar 104(3), 231-239.

DZIK, J. 1999. Evolutionary origin of asymmetry in early metazoan animals, 153-190. In PÁlyi, G., ZuCChi, C. \& CAGLIOTI, L. (eds) Advances in BioChirality. Elsevier Science Ltd., Oxford.

FARRELL, J.R. 1992. The Garra Formation (Early Devonian: Late Lochkovian) between Cumnock and Larras Lee, New South Wales, Australia: stratigraphic and structural setting, faunas and community sequence. Palaeontographica, Abteilung $A$ $222,1-41$.

Fretter, V. \& Graham, A. 1962. British Prosobranch Molluscs. 820 pp. Ray Society, London.

FRÝDA, J. 1992. Mode of life of a new onychochilid mollusc from the Lower Devonian of Bohemia. Journal of Paleontology 66(2), 200-205.

FRÝDA, J. 1997. Oldest representatives of the superfamily Cirroidea (Vetigastropoda) with notes on their early phylogeny. Journal of Paleontology 71(5), 839-847.

FRÝDA, J. 1998. New Silurian and Devonian gastropod genera of Bohemia. Earth Science 52(3), 229-234.

FrÝDA, J. 2000. Some new Givetian (late Middle Devonian) gastropods from the Paffrath area (Bergisches Land, Germany). Memoirs of the Queensland Museum 45(2), 359-374.

FrÝDA, J. 2004. Two new gastropod genera (Porcellioidea, Archaeogastropoda) from the Lower Carboniferous of Belgium. Journal of the Czech Geological Society 49(1-2), 57-61.

FrÝDA, J. \& BlodgetT, R.B. 1998. Two new cirroidean genera (Vetigastropoda, Archaeogastropoda) from the Emsian (late Early Devonian) of Alaska with notes on the early phylogeny of Cirroidea. Journal of Paleontology 72(2), 265-273.

FRÝDA, J. \& BlodgetT, R.B. 1999. New Devonian gastropod genera important for paleogeographic reconstructions. Journal of the Czech Geological Society 44, 293-308.

FrÝDA, J. \& BlodgetT, R.B. 2001. The oldest known heterobranch gastropod, Kuskokwimia gen. nov., from the Early De- vonian of west-central Alaska, with notes on the early phylogeny of higher gastropods. Bulletin of the Czech Geological Survey 76, 39-53.

FrÝDA, J. \& BlodgetT, R.B. 2004. New Emsian (late Early Devonian) gastropods from Limestone Mountain, Medfra B-4 quadrangle, west-central Alaska (Farewell terrane), and their paleobiogeographic affinities and evolutionary significance. Journal of Paleontology 78(1), 111-132.

DOI 10.1666/0022-3360(2004)078<0111:NELEDG >2.0.CO;2

FrÝda, J., Blodgett, R.B., Lenz, A.C. \& Manda, Š. 2008. New porcellioidean gastropods from Early Devonian of Royal Creek area, Yukon Territory, Canada, with notes on their early phylogeny. Journal of Paleontology 82(3), 595-603. DOI 10.1666/07-024.1

FrÝdA, J., Blodgett, R.B. \& LenZ, A.C. 2002. New Early Devonian gastropods from the families Crassimarginatidae (new family) and Scoliostomatidae (new family), Royal Creek area, Yukon Territory, Canada. Journal of Paleontology 76, 244-255.

DOI 10.1666/0022-3360(2002)076<0246:NEDGFT>2.0.CO;2

FRÝDA, J. \& FARRELL, J.R. 2005. Systematic position of two Early Devonian gastropods with sinistrally heterostrophic shells from the Garra Limestone, Larras Lee, New South Wales. Alcheringa 29, 229-240.

FrÝDA, J. \& RoHr, D.M. 2004. Gastropoda, 184-195. In WebBy, B.D., Paris, F., Droser, M.L. \& Percival, I.G. (eds) The Great Ordovician Biodiversification Event. 408 pp. Columbia University Press, New York.

FRÝDA, J. \& RoHR, D.M. 2006. Shell heterostrophy in Early Ordovician Macluritella Kirk, 1927, and its implications for phylogeny and classification of Macluritoidea (Gastropoda). Journal of Paleontology 80(2), 264-271. DOI 10.1666/0022-3360(2006)080[0264:SHIEOM]2.0.CO;2

Geiger, D.L., Nützel, A. \& SASaki, T. 2008. Vetigastropoda, 297-330. In Ponder, W. \& Lindberg, D.L. (eds) Phylogeny and Evolution of the Mollusca. 488 pp. University of California Press, Berkeley and Los Angeles, California.

Gray, J.E. 1850. Catalogue of the Mollusca in the collection of the British Museum. Part II, Pteropoda. 45 pp. E. Newman, London.

HaszPRUnAR, G. 1985. The Heterobranchia - a new concept of the phylogeny of the higher Gastropoda. Zeitschrift für zoologische Systematik und Evolutionsforschung 23, 15-37.

HaVlíčEK, V. \& ŠToRCH, P. 1990. Silurian brachiopods and benthic communities in the Prague Basin (Czechoslovakia). Rozpravy Ústředního ústavu geologického 48, 1-275.

HeIDELberger, D. 2001. Mitteldevonische (Givetische) Gastropoden (Mollusca) aus der Lahnmulde (suedliches Rheinisches Schiefergebirge). Geologische Abhandlungen Hessen 106, $1-291$.

HENDRICKS, J.R. 2009. Sinistral snail shells in the sea: developmental causes and consequences. Lethaia 42, 55-66. DOI 10.1111/j.1502-3931.2008.00103.x

Holzapfel, E. 1889. Die Cephalopoden-führenden Kalke des unteren Carbon von Erdbach-Breitscheid bei Herborn. Paläontologische Abhandlungen (Dames-Kayser), Band 5 (Neue Folge, Band 1), Jena, 1-460.

HoRnÝ, R.J. 2002. Krolmusium, a new genus of the subfamily Agnesiinae (Gastropoda) from the Lower Devonian of Bohe- 
mia (Czech Republic). Časopis Národního muzea, Řada př́irodovědná $171(1-4), 7-11$.

KAIM, A. 2001. Faunal dynamics of juvenile gastropods and associated organisms across the Valanginian transgression-regression cycle in central Poland. Cretaceous Research 22(3), 333-351. DOI 10.1006/cres.2001.0255

Kaim, A. 2004. The evolution of conch ontogeny in Mesozoic open sea gastropods. Palaeontologia Polonica 62, 3-183.

Kiel, S. \& FrÝdA, J. 2004. Nacre in Late Cretaceous Sensuitrochus ferreri - implications for the taxonomic affinities of the Cirridae (Gastropoda). Journal of Paleontology 78(4), 795-797.

DOI 10.1666/0022-3360(2004)078<0795:NILCSF $>2.0 . C O ; 2$

KIRK, E. 1927. Macluritella, a new gastropod genus from the lower Ordovician of Colorado. American Journal of Science 14, 288-291.

Klug, C., Kröger, B., Kiessling, W., Mullins, G. L., Servais, T., FrÝdA, J., Korn, D. \& Turner, S. 2010. The Devonian Nekton Revolution. Lethaia 43, 465-477. DOI 10.1111/j.1502-3931.2009.00206.x.

KNIGHT, J.B. 1931. The gastropods of the St. Louis, Missouri, Pennsylvanian outlier: Aclisina and Streptacis. Journal of Paleontology 5, 1-14.

Knight, J.B. 1941. Paleozoic gastropod genotypes. Geological Society of America, Special Papers 32, 1-510.

KNight, J.B. 1952. Primitive fossil gastropods and their bearing on gastropod classification. Smithsonian Miscellaneous Collections 117(13). 56 pp. Smithsonian Institute, Washington.

KNIGHT, J.B. 1956. New families of Gastropoda. Journal of the Washington Academy of Sciences 46, 41-42.

Knight, J.B., Cox, L.R., Batten, R.L. \& Yochelson, E.L. 1960. Systematic descriptions. In Moore, R.C. (ed.) Treatise on invertebrate paleontology. Part I. Mollusca 1. University of Kansas Press, Lawrence, Kansas.

KoKEn, E. 1896. Die Leitfossilien. 848 pp. C.H. Trachnitz, Leipzig.

Koninck, L.G. de 1883. Faune du calcaire carbonifère de la Belgique, 4 partie, Gastéropodes (suite et fin). Musée Royal d'Histoire Naturelle de Belgique Annales, Série Paléontologique 8, 1-240.

Kuroda, R., Endo, B., Abe, M. \& Shimizu, M. 2009. Chiral blastomere arrangement dictates zygotic left-right asymmetry pathway in snails. Nature 462, 790-794. DOI 10.1038/nature08597

Lehnert, O., Frýda, J., Buggisch, W., Munnecke, A., NütZel, A., KŘižz, J. \& MANDA, Š. 2007. $\delta^{13} \mathrm{C}$ record across the Ludlow Lau Event: new data from mid palaeo-latitudes of northern peri-Gondwana (Prague Basin, Czech Republic). Palaeogeography, Palaeoclimatology, Palaeoecology 245, 227-244. DOI 10.1016/j.palaeo.2006.02.022

Linnaeus, C. 1758. Tomus I. Systema naturae per regna tria naturae, secundum classes, ordines, genera, species, cum characteribus, differentiis, synonymis, locis. Editio decima, reformata. 824 pp. Laurentii Salvii, Holmiae.

Linsley, R.M. \& KieR, W.M. 1984. The Paragastropoda: a proposal for a new class of Paleozoic Mollusca. Malacologia 25(1), 241-254.

MANDA, S̆. \& FRÝDA, J. 2010. Silurian-Devonian boundary events and their influence on cephalopod evolution: evolutionary significance of cephalopod egg size during mass extinctions. Bulletin of Geosciences 85(3), 513-540.

DOI 10.3140/bull.geosci.1174

MANDA, Š. \& KŘ́ǐ, J. 2006. Environmental and biotic changes of the subtropical isolated carbonate platforms during Kozlowskii and Lau events (Prague Basin, Silurian, Ludlow). GFF 128, 161-168.

Manda, Š. \& TuReK, V. 2009. Revision of the Pragian Rutoceratoidea Hyatt, 1884 (Nautiloidea, Oncocerida) from the Prague Basin. Bulletin of Geosciences 84(1), 127-148. DOI 10.3140/bull.geosci.1118

NüTZEL, A. \& FRÝDA, J. 2003. Paleozoic plankton revolution: evidence from early gastropod ontogeny. Geology 31, 829-831. DOI 10.1130/G19616.1

NütZel, A., Lehnert, O. \& FrÝdA, J. 2006. Origin of planktotrophy - evidence from early molluscs. Evolution and Development 8(4), 325-330.

DOI 10.1111/j.1525-142X.2006.00105.x

NütZel, A., LehNERT, O. \& FrÝdA, J. 2007. Origin of planktotrophy - evidence from early molluscs: a response to Freeman and Lundelius. Evolution and Development 9(4), 312-317. DOI 10.1111/j.1525-142X.2007.00166.X

Pan Hua-Zhang, Erwin, D.H., Nützel, A. \& Zhu Xiang-Shui 2003. Jiangxispira, a new gastropod genus from the Early Triassic of China with remarks on the phylogeny of the Heterostropha at the Permian/Triassic Boundary. Journal of Paleontology 77, 44-49.

DOI 10.1666/0022-3360(2003)077<0044:JANGGF>2.0.CO;2

PChelinTSEv, V.F. \& KorobKov, I.A. 1960. Osnovy paleontologii, Mollusca-Gastropoda. 360 pp. Akademiya Nauk SSSR, Moscow.

PeEL, J.S. \& HornÝ, R. 1996. Sinistral hyperstrophic coiling in a Devonian gastropod from Bohemia with an in situ operculum. Palaeontology 39(3), 709-718.

Pelseneer, P. 1893. Introduction à l'étude des Mollusques. Annales de la Société Royale Malacologique de Belgique 27, 31-243.

Perner, J. 1907. Recherches paléontologiques. Volume 4, Gastéropodes. In BARRANDE, J. Système silurien du centre de la Bohême. Prague.

Quintero, I. \& REVILLA, J. 1966. Algunas especies nuevas y otras poco conocidas. Notas y comunicaciones del Instituto Geologico y Minero de Espańa 82, 27-86.

Robertson, R. 1993. Snail handedness. National Geographic Research \& Exploration 9(1), 104-119.

Salvini-Plawen, L. von 1980. A reconsideration of systematics in the Mollusca (phylogeny and higher classification). Malacologia 19, 249-278.

SASAKI, T. 1998. Comparative anatomy and phylogeny of the Recent Archaeogastropoda. The University Museum, The University of Tokyo Bulletin 38, 1-223.

Schilthuizen, M. \& Davison, A. 2005. The convoluted evolution of snail chirality. Naturwissenschaften 92, 504-515.

Schilthuizen, M. \& HaAse, M. 2010. Disentangling true shape differences and experimenter bias: are dextral and sinistral snail shells exact mirror images? Journal of Zoology 282(3), 191-200.

Signor, P.W. \&. BRETT, C.E. 1984. The mid-Paleozoic precursor 
to the Mesozoic marine revolution. Paleobiology 10, 229-245.

Slaví, L. 2004. The Pragian-Emsian conodont successions of the Barrandian area: search of an alternative to the GSSP polygnathid-based correlation concept. Geobios 37(4), 454-470. DOI 10.1016/j.geobios.2003.05.002

Slavík, L., KŘíž, J. \& CARlS, P. 2010. Reflection of the mid-Ludfordian Lau Event in conodont faunas of Bohemia. Bulletin of Geosciences 85(3), 395-414.

DOI 10.3140/bull.geosci.1204

THIELE, J. 1929-35. Handbuch der systematischen Weichtierkunde. 1154 pp. Fischer, Jena.

Ueshima, R. \& Asami, T. 2003. Single-gene speciation by leftright reversal. Nature 425(6959), 679. DOI $10.1038 / 425679$ a

VermeIJ, G.J. 1975. Evolution and distribution of left-handed and planispiral coiling in snails. Nature 254(5499), 419-420.

Wägele, H., Klussmann-Kolb, A., Vonnemann, V. \& Medina, M. 2008. Heterobranchia I, 385-408. In PONDER, W. \& LindBERG, D.L. (eds) Phylogeny and Evolution of the Mollusca.
488 pp. University of California Press, Berkeley and Los Angeles, California.

Wagner, P.J. 1999. Phylogenetics of the earliest anisostrophically coiled gastropods. Smithsonian Contributions to Paleobiology 88, 1-132.

WenZ, W. 1938-1944. Gastropoda, 1-1639. In Schindewolf, O.H. (ed) Band 6, Teil 1-7, Handbuch der Paläozoologie. Borntraeger, Berlin.

WhidBoRne, G.F. 1891. A monograph of the Devonian fauna of the south of England. Part 4, 251-344. Palaeontographical Society, London.

WoOdWARD, S.P. 1854. A manual of the Mollusca; or, rudimentary treatise of Recent and fossil shells. 486 pp. Weale, London.

Yoo, E.K. 1994. Early Carboniferous Gastropoda from the Tamworth Belt, New South Wales, Australia. Records of the Australian Museum 46, 63-120.

ZitTel, K.A. 1895. Grundzüge der Paläontologie (Paläozoologie), Abteilung I, Invertebrata. 971 pp. Oldenburg, München \& Leipzig. 